\title{
O CASTELO (QUASE) VAZIO: ALGO DE GÓTICO EM FRONTEIRA, DE CORNÉLIO PENNA
}

Josalba Fabiana dos Santos

Universidade Federal de Sergipe

\section{Resumo}

O romance brasileiro Fronteira (1935), de Cornélio Penna, possui algumas características góticas bastante relevantes, sendo que a principal é a reconfiguração do castelo medieval no sobrado de uma típica família patriarcal mineira de fins do século XIX. Todavia, essas características surgem em meio a um conflito que se dá na literatura brasileira de um modo geral e na de Cornélio Penna em particular com a tradição europeia. É uma relação de constante admiração e repúdio. O gótico em Fronteira parece assim uma cicatriz, ele assinala o texto como o resultado desse embate, dessa luta.

Palavras-chave: Gótico; Cicatriz; Fronteira; Cornélio Penna.

\section{THE (NEARLY) EMPTY CASTLE: SOMETHING GOTHIC IN FRONTEIRA, BY CORNÉLIO PENNA}

\begin{tabular}{|l|l|l|l|l|}
\hline Ilha do Desterro & Florianópolis & n 62 & p. 319- 340 & jan/jun 2012 \\
\hline
\end{tabular}




\begin{abstract}
The Brazilian novel Fronteira (1935), by Cornélio Penna, is characterized by some very relevant Gothic features. The main one is the reconfiguration of the medieval castle in the house of a typical patriarchal family in the state of Minas Gerais in the late nineteenth century. However, these features arise from a conflict between Brazilian literature in general, and in particular Cornélio Penna's novels, and the European tradition. It is a relationship of constant admiration and repulse. The Gothic in Fronteira is similar to a scar, characterizing the text as a result of such a struggle, such a clash.
\end{abstract}

Keywords: Gothic; Scar; Fronteira; Cornélio Penna.

\title{
Introdução
}

Vários críticos têm aproximado a obra de Cornélio Penna (18961958) do gótico ${ }^{1}$; Luiz Costa Lima, em A perversão do trapezista, foi o primeiro: "deveremos tomar Cornélio como o raro epígono de alguma corrente precedente - do romance gótico, talvez, misturado a Camilo Castelo Branco" (LIMA, 1976, p. 56). A aproximação é um pouco tímida, trata-se de um talvez que Costa Lima não retoma ao longo do seu texto, mas outros críticos a retomam. Comentando a última edição de Fronteira, o primeiro livro de Cornélio, Marília Rothier Cardoso afirma que o autor

[...] constrói sua estratégia narrativa [...] selecionando algumas conquistas da vanguarda, adapta-as a traços do romance gótico e da tradição fantástica. Produz, assim, na contramão do regionalismo em voga, um estilo de alto requinte, capaz de perscrutar a intimidade e sugerir panoramas sócio-históricos, de forma sutil, nebulosa e fragmentária, longe da banalidade realista. (CARDOSO, 2001) 
É justamente da capacidade de "sugerir panoramas sócio-históricos, de forma sutil, nebulosa e fragmentária" através de traços do romance gótico que o presente trabalho tratará. Esses traços são parte das cicatrizes deixadas pelos ingleses ao longo da história nacional, sobretudo de Minas Gerais, que Cornélio Penna percebe e reelabora em suas narrativas.

Inicialmente Cornélio foi pintor, carreira que abandonou pela de escritor, quando então publicou quatro romances: Fronteira (1935), ${ }^{2}$ Dois romances de Nico Horta (1939), Repouso (1949) e A menina morta (1954). O primeiro já permite entrever a obra-prima que se realizará no último. Todas as suas narrativas estão marcadas pelo gótico, mas aqui se tratará de Fronteira, livro inaugural da atmosfera de mistério que se espalhará pelos demais.

A história se desenvolve a partir de um narrador-personagem nunca nomeado que chega ao sobrado onde vive Maria Santa, numa cidade igualmente não nomeada no interior de Minas - provavelmente Itabira. Motivada pelas qualidades milagreiras da sobrinha, Tia Emiliana também se desloca para o sobrado de Maria e, em seguida, a Viajante, outra personagem da qual o leitor não obterá o nome. Há uma expectativa em torno da Semana Santa, momento em que os dotes de Maria devem emergir. A moça entra numa espécie de transe, quando uma multidão de romeiros, portadores de alfinetes com os quais a espetam, assistem extasiados à total ausência de reação daquele corpo que jaz diante deles. Maria nunca sai desse transe, nele morre. Tia Emiliana e a Viajante deixam a cidade furtivamente, portando as oferendas que os romeiros haviam feito à milagreira. E o narrador enlouquece.

O romance de Cornélio Penna não é um gótico no sentido estrito do termo. Escrito e publicado na primeira metade do século $\mathrm{XX}$, ambientado no final do XIX, no Brasil, só por isso não poderia sê-lo. O romance gótico se realizou na Inglaterra, entre a segun- 
322 Josalba Fabiana dos Santos, O castelo (quase) vazio: algo de gótico...

da metade do século XVIII e o início do XIX. Em Gótico tropical (2010), Daniel Serravalle de Sá afirma que as imagens góticas são obscuras, a morte é um tema central e os enredos se desenvolvem entre a realidade e o mundo sobrenatural. $\mathrm{Na}$ mesma sequência, o pesquisador salienta abadias e castelos como cenários recorrentes, onde "é possível que portas se fechem misteriosamente e velas se apaguem com uma súbita rajada de vento". Tudo isso enquanto "personagens se locomovem através de passagens secretas ou se escondem em úmidos recintos subterrâneos" (SÁ, 2010, p. 36). Ainda sobre o gótico, Sá diz se tratar de uma

[...] narrativa que se passa em tempos remotos (frequentemente medievais) e em países longínquos (geralmente Itália, Espanha ou França), a apresentação de tais histórias como traduções de manuscritos perdidos, a presença de espaços vastos e de espaços confinados, a abordagem de aspectos pitorescos e sublimes na natureza. (SÁ, 2010, p. 54)

Várias dessas características são verificáveis em Fronteira: imagens obscuras são constantes, bem como a presença da morte e alusões ao sobrenatural. $\mathrm{O}$ fato de ter sido escrito e publicado no século XX, mas ambientado no anterior e em Minas Gerais, descrita como isolada entre montanhas, também aviva aspectos do gótico. Além disso, Fronteira seria a transcrição de um suposto diário.

Mais uma questão a ser considerada é a biblioteca ${ }^{3}$ do autor, que continha A abadia de Northanger, de Jane Austen, e livros de Ainsworth e Lytton - escritores góticos ou seus parodistas. Ainda que a posse não seja suficiente para comprovar a leitura, ela o é pelo menos como indicação de interesse.

Retomando à crítica feita a Fronteira, Léo Schlafman observa que Cornélio Penna 
[...] encontra no ambiente mineiro as premissas do gótico. Entre as montanhas erguem-se os casarões cheios de sombras, esmagados por telhados enormes. Paredes altas, sótãos, móveis pesados, malas, relógios antigos, escorpiões, aranhas negras - tudo isso forma a moldura dentro da qual atuam presenças impalpáveis, o perigo próximo, ameaçador... (SCHLAFMAN, 2001, p. 14)

Segundo Sá, na narrativa gótica: "A montanha e o castelo são igualmente imagens emblemáticas que encerram associações de poder [...]" (2010, p. 67). Para efeito de uma análise produtiva de Fronteira, este trabalho se iniciará pelo castelo, na verdade, pelo seu equivalente atualizado e travestido: o sobrado. É nele que os personagens atuam e é dele que emana a atmosfera de mistério que propicia o enredo.

\section{O sobrado e o castelo}

O castelo assumia um papel especial dentro da narrativa gótica:

Em uma interpretação mais sinistra [...] o castelo tinha a conotação de um lugar monstruoso onde tiranos feudais ou aristocráticos, isolados dos olhos da sociedade, podiam se entregar à devassidão e a práticas nefastas. Em outra interpretação, o castelo feudal está ligado ao repúdio por um governo despótico, poderes arbitrários e privilégios aristocráticos que não poderiam mais existir no novo mundo. (SÁ, 2010, p. 69-70).

Apesar de emblema de poder, o sobrado em Fronteira, assim como o castelo no gótico, está em ruínas. De maneira que o poder não está no presente, ao menos não na sua plenitude. O sobrado é a imagem desgastada do patriarcalismo que o edificou. As riquezas que erigiram suas paredes se esvaíram, o patriarca está morto, mas as cicatrizes dos seus atos cruéis ainda estão lá. O sobrado resta gran- 
dioso tal como um castelo. Portas e janelas sempre fechadas, móveis pesados e escuros, moradores soturnos e histórias misteriosas.

Nas narrativas góticas tradicionais o isolamento é um ingrediente fundamental que contribui para a atmosfera de medo e mistério reinante. Em Fronteira também. Apesar de construído no meio de uma cidade do interior mineiro, o sobrado e seus habitantes têm pouco ou nenhum contato com ela. $\mathrm{O}$ isolamento é o resultado de uma soma de acontecimentos. Provavelmente o assassinato do noivo de Maria Santa pela família dela há alguns anos é o principal. No presente da narrativa, todos se foram. Não há notícia de pais ou irmãos. Maria vive só com algumas empregadas. Esse isolamento é interrompido, ou revelado, pela presença do narrador, que chega não se sabe de onde e que está ali não se sabe por quê, e de Tia Emiliana, que agencia e explora os dotes milagreiros da sobrinha.

Se por um lado o sobrado guarda em si Maria Santa, essa figura mística e reverenciada, por outro também guarda a memória do assassinato do seu noivo. Santificado e nefasto, bendito e maldito ao mesmo tempo. De todo modo e por causa do duplo signo, o sobrado está imerso em mistério. A cidade não é muito diferente: os habitantes são descritos como fantasmas, sombras fugazes. Além disso, ela está isolada entre montanhas, por sua vez apresentadas como hostis. A natureza em Fronteira é assustadora; grandiosa, mas assustadora, assim como no gótico:

A natureza nos romances góticos frequentemente se reveste de um certo terror, cujo efeito é alcançado por uma retórica do excesso, uma linguagem hiperbólica com ênfase adjetival que torna o cenário grandioso e intimidante. Isso se traduz em cenários como vastas paisagens, montanhas [...]. (SÁ, 2010, p. 38)

Emoldurado e isolado na e pela cidade, que por sua vez está emoldurada pela natureza hostil, o sobrado é descrito como um co- 
fre (PENNA, 1958, p. 61). Um cofre serve para guardar segredos e tesouros. A mulher, principalmente a jovem e solteira, era um dos principais tesouros que o sobrado deveria conter. É basicamente o que afirma Gilberto Freyre: "O sistema patriarcal de família queria as mulheres, sobretudo as moças, as meninotas, as donzelas, dormindo nas camarinhas ou alcovas de feitio árabe: quartos sem janela, no interior da casa [...]" (FREYRE, 2004, p. 317). Essa mulher jovem e solteira seria o elo entre famílias ricas. Por meio das moças, casamentos endogâmicos se realizavam e fortunas se multiplicavam. Enigmática, a narrativa não diz, porém insinua que Maria não é mais virgem. Às vésperas de ser "santificada" pela cidade, num repente, ela afirma: "Não sou digna! mas, não sou digna! agora é tarde! depois do que se passou é tarde! é tarde!” (PENNA, 1958, p. 57). Em seguida, indica ao narrador um quarto onde estaria a "verdade". Aqui descrições realísticas são interrompidas e o sobrenatural atravessa a cena:

Que segredo guardariam aqueles móveis velhos e cansados? / Aproximei-me do leito, e contemplei-o com olhar suspeitoso. / Colchões e travesseiros, enormes, levemente cobertos de poeira, estavam em ordem, com o pano desbotado pelo tempo. Mas pouco a pouco, diante de meus olhos dilatados pela atenção, as suas flores, de um vermelho longínquo, começaram a se mover, aumentaram e espraiaram-se, ora juntando-se em desenhos esquisitos, ora separando-se, em fuga rápida, e se escondiam nos grandes rebordos do espaldar. /Pareciam de sangue seco, restos de crime... / Pareciam de sangue cansado, débil, esbranquiçado... /Pareciam de sangue espumoso, lembrança de ignóbeis volúpias... /Pareciam de sangue! (PENNA, 1958, p. 59)

Assim se inicia a visita do narrador ao quarto que supostamente guarda um dos principais segredos do sobrado e, por extensão, de Fronteira: o motivo desencadeador da morte do noivo de Maria Santa 
e o seu assassino. O sangue participa da descrição inicialmente como um duplo signo: "restos de crime" é uma expressão que alude ao mesmo tempo ao ato sexual entre Maria e seu noivo e à morte do rapaz. Na continuação, o narrador acentua mais a sua visão moralista do sexo.

Recuei com repugnância, e senti, como se tivesse pousado sobre o colchão as minhas mãos, o cavalo dos corpos em suor, agitados por inomináveis estremecimentos. Que gemidos alucinantes teriam batido de encontro àquelas almofadas de madeira, com grandes veios escuros, como o dorso da mão do diabo, de envolta com odores mornos de gozo e de brutalidade. /Todo o quarto parecia agora viver intensamente, e sentia em meus ouvidos um clamor de vida pecaminosa, trêmula, indecente, do crime humano da reprodução, e o seu ambiente poderoso, entontecedor de crueza e nudez, envolveu-me em sua onda amarga. (PENNA, 1958, 59-60)

A visão moralista do narrador é compatível com a do patriarcalismo: o sexo é posto como um crime. E um crime, no sistema patriarcal, só poderia ser punido com outro. O romance não diz quem matou o noivo, mas somente a família de Maria Santa estaria "autorizada" a vingar a desonra a que fora submetida. No capítulo imediatamente seguinte ao da "visão do quarto da verdade", o narrador ouve de um visitante uma menção aos crimes da "família brutal" de Maria e que na cidade: "Disseram mesmo que ela ia casar-se, e aqui esteve hospedado o seu noivo, que saiu desta casa para ser enterrado, e isso deu muito que falar" (PENNA, 1958, p. 62). A um leitor distraído pode passar despercebida a relação entre essas duas passagens (primeiro a do quarto e por último o comentário do visitante), tal a habilidade do autor em trabalhar com capítulos curtos e cortes rápidos, produzindo uma aparência de descontinuidade. Além disso, as possíveis respostas aos enigmas vêm de fontes não muito confiáveis, como a da visão sobrenatural do narrador de um ato sexual ou a de 
um personagem secundário afirmando que a morte do noivo de Maria causou escândalo. São todos recursos narrativos que se prestam à ambiguidade e à dúvida, o que não significa dizer que não há respostas possíveis. Afinal, havia um corpo (o do noivo), havia um motivo (o sexo fora do casamento) e havia a figura vingadora (a família).

Todavia, aniquilando o noivo, a família decreta o seu próprio fim. Aparentemente Maria é a única herdeira. Mas destituída de valor moral e vivendo num sobrado em ruínas, ela não pode mais se casar, pois perdeu todos os atrativos para a sociedade que a cerca. Neste caso, ela se tornou o tesouro que foi guardado porque perdeu o valor.

Depois de fazer sexo com o noivo, Maria teria perdido o seu valor para a família patriarcal e, por extensão, para toda a cidade. Logo, ela é isolada ou presa no sobrado numa atitude exemplar: um aviso a todas as outras mulheres. Maria é a princesa que sobrou no castelo, porém, uma princesa sem valor, a vergonha da cidade que deve ser escondida.

\section{O quadro fantasmagórico}

Ainda em Gótico tropical (2010), Sá discute como certos objetos funcionam como signos de poder. Numa relação de contaminação, esses objetos impregnam o castelo e o castelo os impregna de seus valores (cf. SÁ, 2010, p. 96). Os quadros em Fronteira são uma representação clara de poder. Há vários; no entanto, é num deles que o narrador se concentra, o da avó de Maria Santa. Os homens da família não são mencionados. Todavia, a descrição a seguir reserva à avó um papel de mantenedora da ordem patriarcal:

No maior deles, Dona Maria Rosa, de vestido preto de pregas, o corpete apertado, o decote quadrado muito aberto, que cercava o colo amarelo e enrugado, a boca cerrada voluntariosamente, como a cicatriz de uma navalhada, parecia eternamente à espreita, com 
seu olhar de soslaio, escrutador. A cabeça pendia para a frente, num esforço para escutar bem, não perder uma só palavra, nem qualquer intenção oculta de quem falasse. (PENNA, 1958, p. 30)

A violência está presente, pois a boca de Dona Maria Rosa se assemelha à cicatriz de uma navalhada, comparação que tanto pode remeter ao silêncio ao qual ela teria sido submetida como ao qual ela submetera outros - hipótese que parece mais plausível com o restante da descrição. Na sua imobilidade, o retrato indica um movimento sutil, quase fantasmagórico, ${ }^{4}$ a cabeça que dele pende para ouvir melhor, a cabeça que dele se destaca vigilante para os movimentos no sobrado. Mesmo morta, a velha senhora se mantém atenta, a neta continua subjugada. Morar só, para Maria, não é de forma alguma a possibilidade de uma vida livre, ao contrário, pois ela está presa na casa com a memória de toda a família. A avó de Maria Santa ocupa o lugar do patriarca. É ela quem aparece como autoritária e vigilante - e, estranhamente, a neta se assemelha a ela, segundo o narrador:

Do retrato o meu olhar desceu para Maria Santa, e notei então a semelhança esquisita que havia entre a avó e a neta. Sendo os seus traços tão diferentes, havia, entretanto, entre eles, uma concordância visível, mas inexplicável. Dona Maria Rosa fora uma mulher má, inexorável, de estranho humor. E vi surgir no rosto lívido de Maria Santa, com a boca a sumir numa dobra, a vida que faltava ao quadro. A fixidez das pupilas, que rutilavam na sombra das arcadas superciliares, tornou-se enervante, intolerável, mesmo para mim, que não estava no raio de sua luz mortal. (PENNA, 1958, p. 30)

Novamente o retrato assume um aspecto fantasmagórico, porque a identificação entre Maria Santa e sua avó, além de negativa, é repentina e assustadora. Apenas nesse momento o narrador vê uma na outra, porque a semelhança não está na genética e sim na maldade 
que é transmitida. O quadro da avó é o espelho onde Maria Santa é identificada com a avó, o que relativiza o seu possível papel de vítima. E a luz mortal reproduzida por ela tem um alvo bem específico: "Senti a fascinação irresistível daquele olhar de cólera gelada, que se abatia, como um florete de aço agudíssimo, sobre o rosto do juiz" (PENNA, 1958, p. 31). O lugar deste personagem, o do juiz, em meio a crimes misteriosos, parece, à primeira vista, o de um agente de revelações. Afinal é ele mesmo quem diz na saída: "Eu hei de voltar, e esclarecer muitas coisas!” (PENNA, 1958, p. 32). Mas o leitor será frustrado, porque o juiz, além de não explicar absolutamente nada, ainda contribui para os enigmas, visto que sua fala alude a episódios obscuros, que precisariam ser esclarecidos. Essa será sua derradeira visita, pois ele nunca voltará para os referidos esclarecimentos.

\section{Um "tribunal" que pune - alguns}

No momento em que o juiz deixa o sobrado e enuncia a frase categórica - "Eu hei de voltar, e esclarecer muitas coisas!" (PENNA, 1958, p. 32) -, o narrador vê a cidade rapidamente entre os batentes da porta e se fixa na descrição do edifício da cadeia, "todo cheio de sinais misteriosos" (PENNA, 1958, p. 33), e acrescenta:

Parecia o crânio apodrecido de uma caveira ali enterrada há muitos anos, acocorada, à moda dos índios, no cimo do morro, e que as chuvas e enxurradas fossem descobrindo lentamente. Eu já fizera Maria Santa observar essa semelhança, aumentada pelas duas janelas, enormes e gradeadas, que nos espreitavam de longe, hostilmente. Quando chovia, as águas formavam logo um riacho, que corria pela sua base, formada de pedras irregulares, como grandes dentes maltratados, quase desprendendo-se do gigantesco maxilar [...] - A caveira está babando - dizia eu, a olhar através dos vidros embaciados pela chuva - e a sua baba vem até aqui, até a porta da casa. (PENNA, 1958, p. 33) 
Maria Santa fica perturbada com esta afirmativa, porque, segundo o narrador, a "alusão ao último crime fora demasiado direta" (PENNA, 1958, 34). É visível a triangulação entre o juiz, o crime e a culpa. Maria e o narrador se veem ameaçados pela presença do juiz que acabara de deixar o sobrado e de alguma revelação que dele possa advir relativamente a um crime - ou a mais de um, já que se fala em "alusão ao último". A cadeia, assim como o retrato da avó, funciona como um espelho, afinal a hostilidade que dela reflete e a baba que os ameaça de contágio obviamente estão no receio deles próprios. Como a narrativa é enigmática, o leitor nunca toma conhecimento do que exatamente causa tanto temor, nem mesmo se Maria e o narrador são cúmplices, testemunhas ou as vítimas de um ou mais crimes. No entanto, a palavra crime nem sempre é usada no seu sentido literal. O sexo, como já se viu, é descrito como o "crime humano da reprodução"; o que faz pensar num uso muito mais metafórico, no qual o crime aparece como transgressão. De forma que toda atitude que fere algum código social ou moral - ou patriarcal - é considerada criminosa, inclusive por suas possíveis vítimas, sempre imbuídas de vergonha e culpa.

No romance de Cornélio Penna, percebe-se um constante cruzar e recruzar de fronteiras. Aquilo que é da esfera do público, o crime, se mistura à vida privada e a impregna, e o que é privado vai consequentemente a público.

Todos os acontecimentos são assuntos particulares de pessoas isoladas: eles não podem se realizar no mundo, publicamente, na presença de um coro, eles não estão sujeitos à opinião pública (universal). Adquirem significado especificamente público somente onde se transformam em atos criminosos. O crime é aquele momento da vida privada onde ela se torna, por assim dizer, pública a contragosto. (BAKHTIN, 1988, p. 244) 
Há uma relação intrínseca entre público e privado a partir do pecado e do crime. O pecado é de ordem individual, bem como seus desdobramentos, como a culpa, o remorso, o castigo e a redenção (BAKHTIN, 1988, p. 241). O crime já pertence a outra esfera, pois faz com que o privado se torne público à revelia dos envolvidos. $\mathrm{O}$ ato criminoso é a ponte entre a vida particular e a social. Aquele mundo que não admitia a presença de terceiros passa a ser obrigado a aceitá-los. E o que era segredo entra no domínio público, não é mais restrito ao indivíduo ou àqueles que lhe são próximos. Mesmo atitudes ingênuas e aceitáveis em qualquer outro contexto passam a ser objeto de malícia e de desconfiança.

A vida privada, pela sua própria essência, não dá lugar ao observador, ao terceiro, que estaria no direito de continuamente observá-la, julgá-la, avaliá-la. Ela se desenrola entre quatro paredes, para dois pares de olhos. A vida pública, como qualquer acontecimento que tenha algum sentido social, dirige-se ao público, pressupõe obrigatoriamente um espectador, um juiz, um avaliador; para ele sempre há lugar no acontecimento, ele é seu participante obrigatório (indispensável). (BAKHTIN, 1988, p. 244)

Mas a vida pública em Fronteira não é pública de fato, pois se restringe à relação entre famílias patriarcais que se autoregulamentam. $\mathrm{E}$ por isso que o ato sexual entre Maria Santa e o noivo, ato privado, teria sido "julgado" pela família dela como um crime. Essa mesma família se sentiria à vontade para condenar os "criminosos": assassinar o noivo e prender/isolar Maria. O silenciamento do juiz, representante do Estado, mostra que o poder patriarcal (privado) é maior do que o poder público. $\mathrm{O}$ juiz só se torna uma ameaça porque no presente da narrativa os familiares de Maria estão mortos e o patriarcalismo desgastado.

Segundo Gilberto Freyre: 
[...] desde a chegada ao Rio de Janeiro de D. João, vinha sendo precisamente o declínio do poder patriarcal familial, como que substituído nas cidades pelo poder suprapatriarcal - embora ainda patriarcal em vários dos seus aspectos - não só do bispo como do regente, do rei e, afinal, do imperador. Ou do Estado, representado também pelo poder judiciário de magistrados revestidos de becas orientais para melhor enfrentarem, como rivais, o puro poder patriarcal dos chefes de família. (FREYRE, 2004, p. 424)

O pater familias vai perdendo assim o poder de vida e de morte que detinha sobre todos que estavam sob seu jugo. A vida social e privada começa a ser regulada e julgada pelo Estado. Mas, em Fronteira, o juiz apenas salienta a ausência do patriarca, não a do seu poder. Ausente este, ninguém o substitui. Sutilmente a narrativa aponta uma relação entre o juiz e os crimes da família brutal (PENNA, 1958, p. 62) de Maria Santa, porém silencia sobre julgamentos e punições vindos do poder público. Ao leitor, ciente do contexto histórico e social brasileiro e cético quanto à justiça, só resta imaginar que os criminosos saíram mais uma vez ilesos.

O juiz, em Fronteira, é um arremedo de poder, nada nele indica justiça. Adiante se saberá da sua morte sem maiores explicações. Não se sabe se ele ficara doente, se sofrera algum acidente ou se fora assassinado, mas se sabe que o seu desaparecimento apagou o remorso que o narrador diz ter sentido (PENNA, 1958, p. 109). Afirmativa que se abre para uma insinuação de assassinato do juiz no qual o narrador poderia estar envolvido.

\section{Maria - santa e transgressora}

Como se viu, os retratos são vestígios que apontam para a permanência fantasmagórica da família de Maria. Estão todos mortos, 
mas permanecem presentes. Seus valores morais continuam a impregnar a casa e fazem de qualquer transgressão a eles um ato escandaloso ou um crime. Porém, paradoxalmente, essa presença vigilante também serve de audiência, pois Maria Santa continua a afrontá-los, é como se os obrigasse a testemunhar o jogo de sedução que empreende sobre o narrador; sua atitude é praticamente uma vingança. Por um lado, a família - e a cidade, pois é extensão das ideias da família - confinaram-na, prenderam-na no sobrado-cofre, em relação ao qual eles permanecem vigilantes por meio de todos os objetos que Maria herdou, sobretudo nos quadros. Todavia, a família está morta e os olhares vigilantes não podem impedir as transgressões; em verdade tornam-se testemunhas delas. Assim, Maria não é apenas punida por ter feito sexo com o noivo no passado; ela igualmente pune os parentes, tornando-os testemunhas silenciosas e impotentes diante de tudo que observam. Ela está presa, encerrada para sempre nas grossas paredes do sobrado decaído econômica e moralmente, mas a família sucumbirá com ela, presenciará cada gesto seu até a ruína final. As instituições humanas estão fadadas à ruína no gótico (SÁ, 2010, p. 115), e em Fronteira também.

Diferentemente das heroínas góticas, sempre em fuga, sempre tentando preservar sua virgindade de vilões libidinosos, ${ }^{5}$ Maria Santa perverte as leis do patriarcalismo fazendo sexo com o noivo e seduzindo o narrador que a princípio a aceita reticente e, em seguida, a repele:

Senti [...] uma mão trêmula agarrar-me o braço, e unhas, em garra enterraram-se na minha carne. Um bafo quente chegou-me até a boca, adocicado e morno, e senti que todo o meu corpo se encostava a outro corpo, em um êxtase doloroso e longo, inacabado e insatisfeito[...]. Quando voltei a mim, procurei afastar com violência o monstro que viera das trevas, mas estava só de novo [...], já no meu quarto, lavei a boca, o rosto e as mãos, 
como o fazem os criminosos, para apagar os vestígios de seu crime[...]. (PENNA, 1958, p. 65)

Mais uma vez o sexo surge envolto em culpa e é tratado metaforicamente como se fosse um crime. Porém, isso não impedirá que o narrador se mantenha atraído por Maria e, quando ela entra numa espécie de transe místico que a deixa inconsciente, ele a estupra num verdadeiro ato de necrofilia, pois ela está "impassível, imóvel, como uma estátua funeral" (PENNA, 1958, p. 141). Próximo do gozo, ele afirma:

Não me parecia cometer um crime moral, ao desvendar vagarosamente, um a um, os melancólicos segredos daquele corpo que todo ele se me oferecia e se recusava, ao mesmo tempo, em sua longínqua imobilidade. Era uma caridade incomensurável que ele praticava, inconsciente, mas, por isso mesmo, mais valiosa e quase divina pela sua inocência puríssima, sobre-humana. (Penna, 1958, p. 146)

Ironicamente, quando o ato sexual deixa de ser consentido e compartilhado, portanto passa a ser violento, ele deixa de parecer um crime para o narrador.

\section{Além do gótico}

A cultura inglesa se faz presente em Fronteira por meio de outros aspectos além do gótico. Logo na primeira página do livro, ainda atordoado pela viagem que acabara de realizar, o narrador afirma: "Leio, em minha memória preguiçosa, um grande cartaz com dizeres em inglês e que aparece de surpresa na escuridão, indicando a entrada das minas de ouro abandonadas" (PENNA, 1958, p. 9). Essa frase pode ser lida como uma metáfora. $\mathrm{O}$ cartaz que indica o aces- 
so para as minas arruinadas pela cobiça das companhias inglesas se sobrepõe ao início do romance, a sua entrada. Se o narrador seguisse as palavras em inglês, entraria num universo de riquezas. Ou melhor, entraria num universo que um dia fora de riquezas, mas que no presente da narrativa é apenas memória. A história que as minas abandonadas contam é a história de uma pilhagem. As riquezas se foram, somente seus vestígios ficaram estampados.

O simples uso da língua inglesa no cartaz não seria suficiente para se estabelecer uma relação com o gótico, mas o que vem no interior do romance é. A mesma língua que indica a entrada para mais uma antiga empreitada dos ingleses no Brasil metaforicamente anuncia o gótico que a narrativa contém. A mina contém o que não há mais, nela consta o vazio, a marca; ela se tornou uma cicatriz, um vinco na terra. Também o gótico, enquanto período estético produtivo, inserido num determinado contexto político, histórico e social, já não existe; o que o romance contém são suas marcas, suas cicatrizes.

Num capítulo bem posterior ao do cartaz escrito em inglês, essa língua e suas cicatrizes reaparecem. Maria Santa quer aprender inglês com Miss Ann, da Golden Mining. O desejo da moça está ligado a outro: ler os poetas daquela língua. A admiração aparece na leitura e tradução do Paraíso perdido feitas pelo narrador, apesar do estado em que se encontrava a velha edição: "com a capa de couro toda comida, em caprichosos desenhos, pelos cupins que devoram lentamente toda a cidade do Rio de Janeiro" (PENNA, 1958, p. 67). De maneira que mais uma vez a ruína e a decadência se revelam. Revelações que se fazem sobre outras, pois assim como os insetos devoram os livros e o Rio de Janeiro, também os ingleses devoraram no século XIX, por meio da Golden Mining e outras companhias, as riquezas que os portugueses não levaram anteriormente. Mas o Paraíso perdido continua a encantar: "É um livro de magia [...] e como deve ser 
bonito isso que você está dizendo" (PENNA, 1958, p. 68), comenta Maria. O momento inspira nela a realização de um verdadeiro ritual:

[...] com natural solenidade, muito séria, estendia-me os braços, carregando o pobre alfarrábio e apresentava-o como os antigos pajens entregavam as joias reais - pousadas em almofadas - dando assim uma inesperada gravidade ao seu ato, e fazia reviver um pouco o luxo antigo da desconjuntada e rendilhada encadernação, cujos dourados brilhavam, renovados por um momento, naquele gesto que parecia um maravilhoso milagre de vida, na atmosfera de morte e desconfiança que nos envolvia. (PENNA, 1958, p. 68)

Novamente surge o contraste entre o luxo antigo e a ruína atual, já entrevista no título do livro de Milton: Paraíso perdido - o que era bom deixou de sê-lo. Contraste presente ao longo de toda a narrativa, no sobrado, na cidade, em Minas Gerais. Na sequência, Maria Santa repentinamente retoma ao seu semblante obscuro e reafirma o tom enigmático da narrativa: "E você ficará aqui para sempre [...] e não me fará perguntas [...]" (PENNA, 1958, p. 68). Revelar enigmas ou dar respostas seria reavivar dores, mas não fazê-lo está longe de significar uma situação confortável, pois as cicatrizes estão lá e podem ser lidas. As cicatrizes no texto também contam histórias.

Ao utilizar alguns elementos do gótico em sua narrativa, Cornélio Penna consegue construir vários enigmas, o que não significa dizer que não possam ser enfrentados e até solucionados pelo leitor. Diferentemente da estética inglesa, no entanto, que tende a resolver os mistérios no final, em Fronteira, alguns são mantidos, o que faz ecoar uma frase de A menina morta, o último romance do escritor: "Tudo devia ter um significado oculto e simbólico, e as perguntas eram com certeza de alcance mais longo do que as respostas [...]" (PENNA, 1997, p. 196). 


\section{Considerações finais sobre uma cicatriz}

Funcionando como uma cicatriz no texto de Cornélio Penna, o gótico, de certa forma, fala além de si próprio, pois remete a outras cicatrizes feitas ao longo da história nacional. Uma cicatriz, em geral, é feita a partir de uma dor. Depois que a dor se esvai, a cicatriz fica como uma memória. A relação entre a literatura brasileira e a tradição literária, sobretudo europeia, é ambivalente: feita de admiração e de negação. Cornélio se vale de características do gótico, mas isso é um movimento que se realiza em dois sentidos: no reconhecimento e no repúdio. Assim como se vê em Fronteira, a admiração, quase devoção, de Maria Santa pelos poetas ingleses, também se vê a cidade quase abandonada, pilhada de suas riquezas num passado mais remoto pelos portugueses (que as enviaram em grandes lotes para a Inglaterra) e no presente da narrativa, pelos próprios ingleses. Todavia, ironicamente, a mesma presença inglesa que fora nefasta produzindo ruína, possibilita o cenário exato para a criação do romance corneliano dentro de um viés gótico.

Uma cicatriz é uma marca, um sinal, uma distinção. Há cicatrizes de nascença, cunhadas não se sabe necessariamente em qual situação. Porém, normalmente é de uma marca adquirida por meio de algum tipo de agressão à pele que se pensa quando se fala em cicatriz: um machucado, um tombo, uma pancada, uma briga, um acidente, uma cirurgia. Um instrumento cortante ou perfurante pode causar uma cicatriz. Algum tipo de confronto também. Uma cicatriz apela ao imaginário da dor - mesmo onde muitas vezes ela não ocorreu. Ao olhar para alguém que porta uma cicatriz se imagina de imediato uma agressão, inclusive autoinfligida. A cicatriz atualiza ou inventa o seu próprio passado. Uma cicatriz é uma ruptura, às vezes, produzida a partir de uma incisão. A cicatriz indica um a mais, uma adição que por sua vez 
implica descontinuidade, desvio; algo que não estava lá porque não precisava estar. A cicatriz não é necessária, todavia ela está lá, ela é. Ela ocupa um espaço que não lhe pertence e o modifica. A cicatriz é uma diferença, um sinal de reconhecimento; o que era igual de repente se distingue. A cicatriz gera a diferença no seio da repetição.

Na obra de Cornélio Penna, cicatriz é uma metáfora constante, normalmente ligada à dor, que, às vezes, assume um caráter mais íntimo. Como para Dodôte, protagonista de Repouso, o terceiro romance do autor: "Estava certa que seria escrava de sua memória, e todas as frases que dissera, calculadamente formadas, todas as concessões que fizera, friamente, ficariam como cicatrizes deformantes em sua alma” (PENNA, 1998, p. 152). Em outras situações, a dor é mais contundente e se liga à violência. No exemplo a seguir, uma das personagens de A menina morta observa a plantação de café:

[...] viu o quadro severo e hostil que sempre encontrava todos os dias ao despertar. Era a colina pesada, robusta, a erguer-se dificilmente do chão, com o dorso carregado de cafezais, separados ao meio por vala profunda, em riso aberto na terra vermelha quase cor de sangue, em longa cicatriz. (PENNA, 1997, p. 234)

O contexto histórico de A menina morta é o do II Império e da escravidão. A alusão é sutil, mas legível: a longa cicatriz vermelha não está na terra, está no dorso nu dos escravos que nela trabalham e que são constantemente brutalizados. O riso, se riso há, só pode advir dos algozes, do sistema patriarcal e escravocrata que produziu, não os cafezais, e sim as cicatrizes. Essa citação de A menina morta se liga a outra, já vista, de Fronteira, onde a violência também está presente. Na passagem do quadro da avó de Maria Santa, a boca de Dona Maria Rosa é "cerrada voluntariosamente, como a cicatriz de uma navalhada" (PENNA, 1958, p. 30). Já se viu que a velha senhora 
é associada ao patriarcalismo por causa do seu aspecto autoritário e a comparação da sua boca com a cicatriz de uma navalhada só reforça essa ideia e o seu caráter violento.

Em Fronteira, por mais que haja admiração em torno dos ingleses, eles estão inseridos num contexto em que a dor e a violência são constantemente rememoradas. O próprio gótico é uma estética marcada pela violência ou pela sua potencialidade, bem como pelo horror e pelo medo. Para o leitor de hoje, absorvido por gêneros bem mais radicais, pode soar risível alguns dos quadros pintados pelo gótico, mas não passará despercebida a intenção de causar apreensão. De forma que o gótico se insere em Fronteira "como a cicatriz de uma navalhada", ele vinca o texto com a sua violência sempre à espreita.

Os recursos estéticos utilizados por Cornélio Penna podem insinuar uma repetição, uma influência à qual ele se sujeitou por uma série de circunstâncias históricas e sociais, mas indicam uma tensão que tem como resultado algo que não é o gótico. Quando ele o retoma, retoma um mesmo que na verdade já é outro, porque lê o gótico com olhos de cidadão brasileiro da primeira metade do século XX. O escritor só pode recriá-lo criando outra coisa que não é mais o gótico propriamente dito. Em outras palavras, dessa vez as de Deleuze: “[...] a mais exacta repetição, a mais rigorosa repetição, tem, como correlato, o máximo de diferença" (DELEUZE, 2000, p. 39). Ou para falar mais poeticamente: "A lei reúne a mudança das águas à permanência do rio." (DELEUZE, 2000, p. 43).

\section{Notas}

1. Não se abordará aqui estudos que destacaram nos romances de Cornélio Penna aspectos como o estranho, o grotesco, o macabro, o misterioso, o fantasmagórico, por exemplo, porque este trabalho ficaria muito extenso. Optou-se assim por restringir as citações àqueles críticos que se utilizaram da palavra gótico. 
2. Este romance foi adaptado para o cinema com o mesmo título, por Rafael Conde, em 2008.

3. A Coleção Cornélio Penna, do Instituto de Estudos da Linguagem (Unicamp), possui os livros aqui mencionados.

4. Segundo Sá (2010, p. 48), quadros fantasmagóricos faziam parte da parafernália gótica.

5. Sá observa uma associação entre "inocência perseguida" e "perigo iminente" no gótico (2010, p. 74).

\section{Referências}

BAKHTIN, Mikhail. Formas de tempo e de cronotopo no romance. In: BAKHTIN, Mikhail. Questões de literatura e de estética. São Paulo: Ed. Unesp; Hucitec, 1988. p. 211-362.

CARDOSO, Marília Rothier. Paratexto. In: PENNA, Cornélio. Fronteira. Rio de Janeiro: Artium, 2001.

DELEUZE, Gilles. Diferença e repetição. Trad. Luiz Orlandi e Roberto Machado. Lisboa: Relógio D’Água, 2000.

FREYRE, Gilberto. Sobrados e mucambos. 15. ed. São Paulo: Global, 2004.

LIMA, Luiz Costa. A perversão do trapezista: O romance em Cornélio Penna. Rio de Janeiro: Imago, 1976.

PENNA, Cornélio. A menina morta. Rio de Janeiro: Artium, 1997. . Repouso. Rio de Janeiro: Artium, 1998.

. Fronteira. Romances completos. Rio de Janeiro: José Aguilar, 1958. p. 9-167. SÁ, Daniel Serravalle de. Gótico tropical: o sublime e o demoníaco em O Guarani. Salvador: Edufba, 2010.

SCHLAFMAN, Léo. O outro lado da fronteira. In: PENNA, Cornélio. Fronteira. Rio de Janeiro: Artium, 2001. p. 11-18.

[Recebido em 02/02/2012. Aprovado em 19/04/2012] 